\title{
Root growth and distribution in sugarcane cultivars fertigated by a subsurface drip system
}

\author{
Augusto Yukitaka Pessinatti Ohashi $\left({ }^{1 *}\right)$; Regina Célia de Matos Pires ( $\left.{ }^{1}\right)$; Rafael Vasconcelos Ribeiro $\left({ }^{2}\right)$; \\ André Luiz Barros de Oliveira Silva (') \\ (') Agronomic Institute (IAC), Center for Research and Development in Ecophysiology and Biophysics, P.O. Box 28, 13075-630 \\ Campinas (SP), Brazil. \\ (2) University of Campinas (UNICAMP), Institute of Biology, Department of Plant Biology, P.O. Box 6109, 13083-970 Campinas \\ (SP), Brazil. \\ (*) Corresponding author: augusto.ohashi@gmail.com
}

Received: Sept. 1, 2014; Accepted: Dec. 23, 2014

\begin{abstract}
Despite of the agronomic importance for water management, few studies of sugarcane roots have been performed under field conditions during the crop cycle. The aim of this study was to determine the cumulative root density $\left(L_{A}\right)$, root distribution on soil profile and the effective rooting depth (ERD) for three sugarcane cultivars using the minirhizotron method. A field experiment was done with sugarcane cultivars IACSP94-2094, IACSP94-2101 and SP79-1011 grown under subsurface drip fertigation. Soil chemical and physical characteristics were also evaluated. Root evaluations were taken at 38, 58, 123,185 and 205 days during the second ratoon, considering the soil profile until $0.8 \mathrm{~m}$ depth. The highest $\mathrm{L}_{\mathrm{A}}$ and root growth rates were found up to $0.4 \mathrm{~m}$ soil layer for all cultivars. Root growth rate varied during the crop cycle, with the highest values being found between 38 and 58 days after ratoon (DAR). There was a genotypic variation in root growth, with IACSP94-2101 showing the highest $\mathrm{L}_{A}$ of $12.9 \mathrm{~mm} \mathrm{~cm}^{-2}$. The total root length observed around the tube $\left(0.16892 \mathrm{~m}^{2}\right)$ was $10.8,5.9$ and $2.5 \mathrm{~m}$ up to $0.8 \mathrm{~m}$ depth for IACSP94-2101, SP79-1011 and IACSP94-2094, respectively at 205 DAR. The effective rooting depth varied during the cycle for IACSP94-2094, but all cultivars presented an effective depth of $0.4 \mathrm{~m}$ at 205 DAR.
\end{abstract}

Key words: Saccharum spp., irrigation, water management, effective rooting depth, root growth rate.

\section{INTRODUCTION}

The demand for water use by domestic, industrial, energy, leisure, fishing and agricultural sectors is increasing. Considering the different uses the highest volume is demanded by agricultural practices such as irrigation. Nevertheless it is important to highlight that food and bioenergy demand is also increasing and water use efficiency in agricultural systems must be improved by using the most appropriate irrigation method and water management. The subsurface drip irrigation system contributes to water savings, maintaining or even increasing the agricultural production as compared to other irrigation methods (Kandelous \& Šimůnek, 2010) and allows the nutrient application by fertigation at the right time and place, increasing the nutrient uptake efficiency and reducing its losses by leaching.

Irrigation has become an interesting cultural practice to improve crop yield and sustainability in adequate and marginal sugarcane growing areas. The knowledge of root system distribution is fundamental to understand water and nutrient uptake (Smith et al., 2005), to improve water management and also to provide data for crop yield forecasting models. Concerning water management, there are two important parameters: fine root length or root surface area (van Noordwijk, 1993) and the effective rooting depth (ERD). Irrigation studies in Brazil usually consider ERD as the depth in which $80 \%$ of the fine roots are found (Cunha et al., 2010). ERD is an essential parameter to determine soil water availability and then water management in crop systems (Allen et al., 1998).

As compared to canopy traits, there is still few data about root systems and this lack of information is mainly due to the methodological difficulties related to root data sampling (Muñoz-Romero et al., 2010). In addition, the variability of soil physical, chemical and biological properties may result in variable information about root system distribution (van Noordwijk, 1993; Vasconcelos et al., 2003). In fact, roots have high plasticity, changing their form and size when varying soil conditions (Smith et al., 2005). For example, distribution of sugarcane root system was strongly affected by water supply throughout the 
crop cycle (Laclau \& Laclau, 2009). As root distribution and quantity are genotype- and environmental-dependents, choosing the best irrigation and fertigation practices on sugarcane crop is not an easy task and they should be evaluated in each growing condition (Smith et al., 2005).

Data about sugarcane root system growth and distribution are still scarce and most of data was reported a long time ago, with sugarcane cultivars that are not cultivated extensively nowadays (Smith et al., 2005). In Brazil, there are few studies about sugarcane root system (Otto et al., 2009; Vasconcelos et al., 2003). When considering samplings along the crop cycle, the data is even scarcer. Azevedo et al. (2011) have tested the root intersection counting combined with the soil core-sampling method in three sugarcane growth stages, whereas Laclau \& Laclau (2009) have used the intersection counting method at the end of crop cycle and used the soil core-sampling method to assess the root development along the cycle in six growth stages. Unfortunately, there is no recent data about the assessment of sugarcane root system using non-destructive methods, such as minirhizotrons, which allow the monitoring of root growth along the crop cycle under field conditions. In fact, the only study with minirhizotron in sugarcane crop was carried out by Ball-Coelho et al. (1992) under rainfed conditions.

To improve our understanding about sugarcane root dynamics under field conditions, the aim of this study was to evaluate root growth and distribution in soil profile of three sugarcane cultivars fertigated by subsurface drip system.

\section{MATERIALS AND METHODS}

\section{Site}

The study was carried out in Campinas (SP), Brazil (22 ${ }^{\circ} 54^{\prime} \mathrm{S}, 4^{\circ} 05^{\prime} \mathrm{W}$ and $669 \mathrm{~m}$ a.s.l.), where the average air temperature during 1890 to 2010 varied from $23.8^{\circ} \mathrm{C}$ in February to $17.8^{\circ} \mathrm{C}$ in July and the average annual rainfall was $1398 \mathrm{~mm}$. The rainfall is not well distributed along the year with humid season during the summer and dry season in the winter (Blain, 2009). The air temperature and rainfall were monitored with an automatic weather station installed at $100 \mathrm{~m}$ from the experimental area.

The soil was classified as Latossolo Vermelho eutrófico (EMBRAPA, 2013). It is well drained and clay content ranges from 400 to $510 \mathrm{~g} \mathrm{~kg}^{-1}$ until $0.8 \mathrm{~m}$ depth (Table 1 ). The soil bulk density was sampled at depths of $0.1,0.2$, $0.3,0.4,0.6$ and $0.8 \mathrm{~m}$, with two replicates per depth. The critical bulk density based on the least limiting water range (BDc-LLWR) and on observed root and/or yield restriction in the field (BDc-Rest) were both calculated according to Reichert et al. (2009) using the soil clay content. A soil
Table 1. Soil particle distribution $\left(\mathrm{g} \mathrm{kg}^{-1}\right)$ down to a depth of $0.8 \mathrm{~m}$

\begin{tabular}{ccccc} 
Depth $(\mathbf{m})$ & Gross sand & Fine sand & Silt & Clay \\
\hline 0.1 & 290 & 130 & 160 & 420 \\
0.2 & 300 & 110 & 190 & 400 \\
0.3 & 270 & 110 & 190 & 430 \\
0.4 & 250 & 110 & 180 & 460 \\
\hline 0.6 & 190 & 90 & 230 & 490 \\
\hline 0.8 & 210 & 90 & 190 & 510 \\
\hline
\end{tabular}

penetrometer device (Stolf et al., 1983) was used to evaluate the soil penetration resistance (PR), with six replications per cultivar. Soil chemical analysis was performed at January 2013 with one soil sample composed by ten sub-samples collected with auger sampling in seven depths: $0.1,0.2,0.3$, $0.4,0.6,0.8$ and $1.0 \mathrm{~m}$ in each cultivar area.

\section{Sugarcane cultivars}

The sugarcane cultivars (Saccharum spp.) evaluated were IACSP94-2094, IACSP94-2101 and SP79-1011. While IACSP94-2101 is responsive to nutrient and water availability, IACSP94-2094 and SP79-1011 are unresponsive (Landell \& Bressiani, 2008). Sugarcane field was arranged in 20 planting rows with $30 \mathrm{~m}$ long each and spaced $1.5 \mathrm{~m}$ aside, totaling $900 \mathrm{~m}^{2}$ per cultivar. Sugarcane planting was done in May 2010, with approximately 18 gems per meter at a depth of $0.25 \mathrm{~m}$. The first and second harvests were obtained in December 2011 and October 2012 and the experimental period was from October 2012 to May 2013, with five evaluation times until 205 days during the second ratoon (DAR), which was the last evaluation date.

\section{Irrigation and fertigation}

Irrigation was applied by subsurface drip system from December 2012. The irrigation system was installed during planting at a depth of $0.2 \mathrm{~m}$. The nominal flow rate of the emitters was $1.6 \mathrm{~L} \mathrm{~h}^{-1}$ and they were spaced $0.5 \mathrm{~m}$ aside. The irrigation management was based on soil moisture evaluated with the capacitance probe model Diviner-2000 (Sentek Sensor Technologies, Stepney, Australia). For this management three access tubes with internal diameter of $0.051 \mathrm{~m}$ were installed until $1.25 \mathrm{~m}$ depth in each cultivar area. Soil moisture was estimated every $0.1 \mathrm{~m}$ until $1.0 \mathrm{~m}$ depth. Daily irrigation was done to replace soil water and reach the upper limit of soil water retention capacity. The total amount of phosphorus and $40 \%$ of nitrogen and potassium requirements were applied after the second harvest as solid fertilizers. The remaining of $\mathrm{N}$ and $\mathrm{K}$ was applied weekly by fertigation as $\mathrm{KCl}$ and $\mathrm{Ca}\left(\mathrm{NO}_{3}\right)_{2}$, between 161 and 315 DAR. 


\section{Analysis of root system}

Considering the need for reducing time, labor and cost of the traditional methods of root analysis, the minirhizotron technique is an alternative method for evaluating root development (Muńoz-Romero et al., 2010). This method is based on the visualization of root growth in soil profile by catching pictures or videos through a transparent interface. As a non-destructive method, it allows the monitoring of root growth many times in a same spot (Dannoura et al., 2008; Kirkham et al., 1998).

Three access tubes with $1.05 \mathrm{~m}$ length were installed in each cultivar area. To avoid light and water entering tube tops were covered with dark plastic. The images were caught with Root Scanner CI-600 ${ }^{\mathrm{TM}}$ (CID Bio-Science Inc., Camas, WA, USA) in five assessments: 38, 58, 123, 185 and 205 DAR. Four images per access tube representing 0.2 $\mathrm{m}$ depth each were obtained, resulting in 0.0-0.8 m depth analysis. The images were analyzed with the software

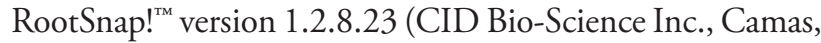
WA, USA). The root length (L) was initially obtained and then the cumulative root density $\left(\mathrm{L}_{\mathrm{A}}\right)$ was estimated as $\mathrm{L}$ normalized by the $422.3 \mathrm{~cm}^{2}$ sampling area of each window (Box, 1993; Smit et al., 2000), totaling $0,16892 \mathrm{~m}^{2}$ per access tube. The total amount of roots was estimated in each sample site and then the relative distribution in soil profile was calculated. The root growth rate was obtained by considering the $\mathrm{L}_{\mathrm{A}}$ increase between two consecutive samplings and the time (days) between samplings.

It was calculated the $\mathrm{L}_{\mathrm{A}}$ standard error (s.e.) for each cultivar and each soil layer and it was adjusted an exponential equation using the CurveExpert software version 1.4 (Hyams, 2009).

\section{RESULTS AND DISCUSSION}

\section{Environmental conditions}

The cumulative rainfall and irrigation during the experimental period (from October 2012 to May 2013) were $905.5 \mathrm{~mm}$ and $315 \mathrm{~mm}$, respectively (Figure 1). The mean daily air temperature ranged from 17 to $29^{\circ} \mathrm{C}$ (Figure 1). According to Liu et al. (1998), there is variation in estimates for sugarcane base temperature depending of phonological stage and also among cultivars. However, it has been stated that temperatures above $18^{\circ} \mathrm{C}$ do not restrict the sugarcane development. Thus, during the experimental period, lower temperature values were only observed in few days.

The soil bulk density increased from $1.48 \mathrm{Mg} \mathrm{m}^{-3}$ in the upper soil layer to $1.63 \mathrm{~g} \mathrm{~cm}^{-3}$ at $0.2 \mathrm{~m}$ and then decreased, reaching $1.21 \mathrm{Mg} \mathrm{m}^{-3}$ at $0.8 \mathrm{~m}$ depth (Figure 2). The 0.2 and $0.3 \mathrm{~m}$ depth layers presented higher values for soil bulk density than the calculated BDc-LLWR and BDc-

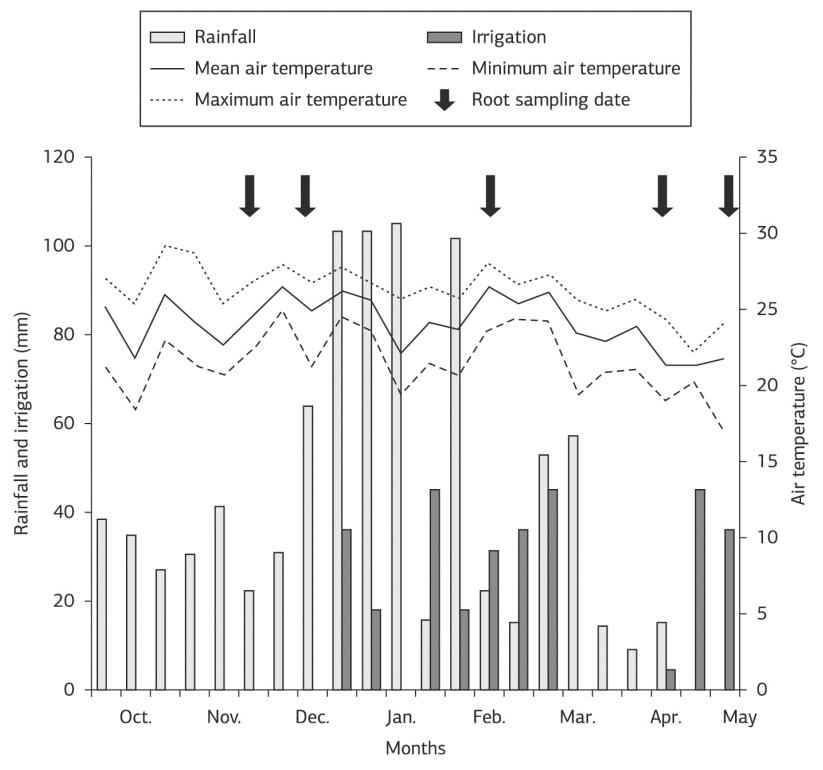

Figure 1. Rainfall, irrigation and average, maximum and minimum air temperature during the experimental period. Data represent the cumulative rainfall and irrigation and mean temperature values for 10 days period. Arrows indicate the sampling times.

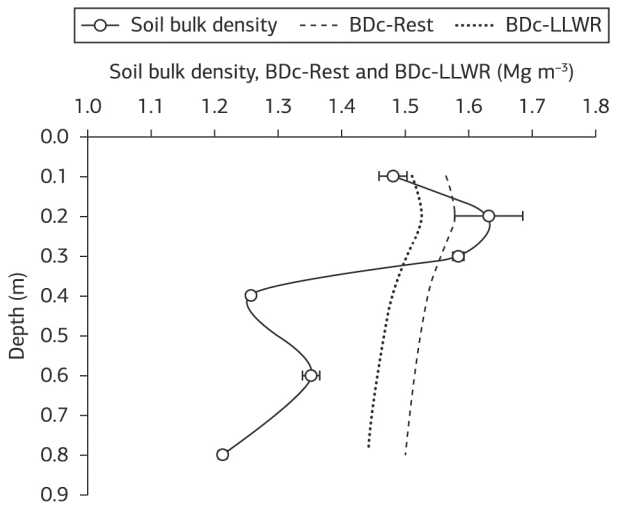

Figure 2. Mean soil bulk density, critical bulk densities considering the least limiting water range (BDc-LLWR) and the restriction to root elongation or yield decrease (BDc-Rest) down to a depth of $0.8 \mathrm{~m}$. Each symbol represents the mean value of two replications ( \pm s.e.).

Rest (Figure 2), which could result in possible restriction to root growth.

The highest soil penetration resistance (PR) was measured at the depth of $0.3 \mathrm{~m}$ (Figure 3a), slightly below the depth of higher soil bulk density (Figure 2), where soil water content was higher due to its proximity to the emitter (Figure 3b). Considering the critical PR of $2 \mathrm{MPa}$ in which root growth may decline (Baquero et al., 2012; Sojka et al., 1990), we have additional evidence that soil conditions likely limited root growth. The maximum PR value observed was $2.91 \mathrm{MPa}$ in IACSP94-2101 area, with the soil layer 0.2-0.7 m showing values higher than $2.0 \mathrm{MPa}$. The other two areas cultivated with SP79-1011 and IACSP94-2094 had PR higher than 2.0 MPa in soil layer $0.2-0.6 \mathrm{~m}$ and $0.1-0.4 \mathrm{~m}$, respectively (Figure 3a). 
The soil base saturation was higher than $60 \%$ and the minimum $\mathrm{pH}\left(\mathrm{CaCl}_{2}\right)$ was 4.5 up to $0.4 \mathrm{~m}$ depth (Table 2). These values were not limiting to sugarcane crop in the State of Sao Paulo, Brazil Quaggio \& van Raij (2008) and van Raij et al. (1996) have stated that sugarcane is more tolerant to aluminum toxicity and soil acidity than other Poaceae plants. Soil Ca and Mg content reduced with depth (Table 2);

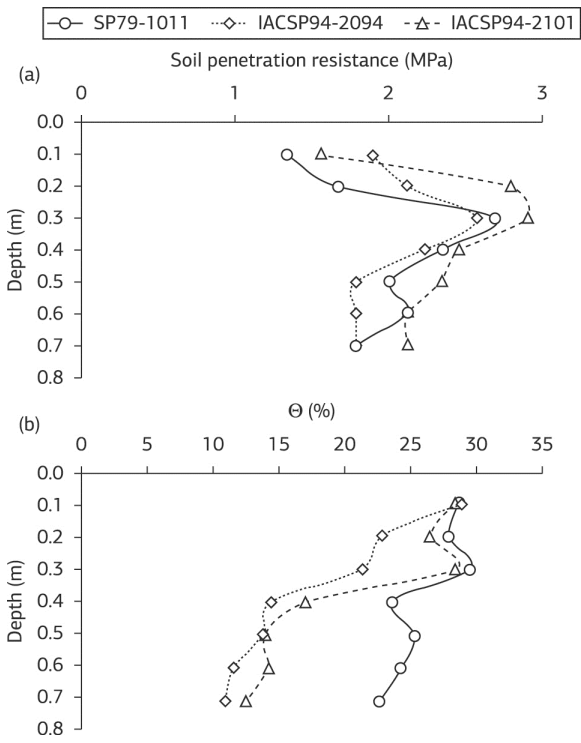

Figure 3. Soil penetration resistance (a) and volumetric soil water content $(\Theta ; \mathrm{b})$ down to a depth of $0.7 \mathrm{~m}$ in areas cultivated with three sugarcane varieties. Each symbol represents the mean value of six replications. however, their values were higher than the recommendation for sugarcane (van Raij et al., 1996). However, soil P, K and organic matter contents below $0.3 \mathrm{~m}$ soil depth were low when considering the standard values, $13 \mathrm{mg} \mathrm{kg}^{-1}$ for $\mathrm{P}$ and $1.6 \mathrm{mmolc} \mathrm{dm}^{-3}$ for K (van Raij et al., 1996).

\section{Cumulative root density}

The highest $\mathrm{L}_{\mathrm{A}}$ values were obtained in IACSP94-2101, followed by SP79-1011, and IACSP94-2094 (Figure 4). $\mathrm{L}_{\mathrm{A}}$ increased until 185 DAR in IACSP94-2101 and SP791011, remaining around 12.9 and $7.5 \mathrm{~mm} \mathrm{~cm}^{-2}$ afterwards respectively (Figures 4a,b). Interestingly, IACSP94-2094 showed an increasing $\mathrm{L}_{\mathrm{A}}$ trend until 205 DAR, reaching maximum $\mathrm{L}_{\mathrm{A}}$ of $3.6 \mathrm{~mm} \mathrm{~cm}^{-2}$ (Figures $4 \mathrm{c}$ ). In all cultivars, high $\mathrm{L}_{\mathrm{A}}$ was found at $0.0-0.2 \mathrm{~m}$ soil layer, which is in agreement with high nutrient availability as presented by soil chemical analysis (Table 2). In fact, the highest $\mathrm{Ca}$ and $\mathrm{P}$ availability occurred up to $0.2 \mathrm{~m}$ depth, favoring sugarcane root growth in this soil layer. When comparing to the other cultivars, IACSP94-2101 presented higher $\mathrm{L}_{\mathrm{A}}$ value even with low soil $\mathrm{P}$ availability in soil layers below $0.3 \mathrm{~m}$ depth (Figure 4; Table 2).

The total root length observed around the access tube was 10.8, 5.9 and $2.5 \mathrm{~m}$ up to $0.8 \mathrm{~m}$ depth for IACSP94-2101, SP79-1011 and IACSP94-2094, respectively (Figure 5). Such values represent a large root length considering minirhizotrons with small area of observation $\left(0.16892 \mathrm{~m}^{2}\right)$.

Table 2. Soil chemical analysis for areas in which three sugarcane cultivars were grown. $\mathrm{OM}=$ Organic matter; CEC = Cation-Exchange Capacity; BS = Base Saturation

\begin{tabular}{|c|c|c|c|c|c|c|c|c|c|c|c|}
\hline \multirow[t]{2}{*}{ Cultivar } & \multirow{2}{*}{$\begin{array}{c}\text { Soil } \\
\text { layers }\end{array}$} & \multirow[t]{2}{*}{$\mathrm{pH}$} & \multirow{2}{*}{$\begin{array}{c}\text { OM } \\
\text { g kg-1 }^{-1}\end{array}$} & \multirow{2}{*}{$\frac{\mathrm{P}}{\mathrm{mg} \mathrm{kg}^{-1}}$} & K & $\mathrm{Ca}$ & Mg & Al & $\mathbf{H}$ & CEC & \multirow{2}{*}{$\begin{array}{l}\text { BS } \\
\%\end{array}$} \\
\hline & & & & & \multicolumn{6}{|c|}{ mmolc dm dm $^{-3}$} & \\
\hline \multirow{7}{*}{ 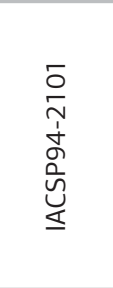 } & $0.0-0.1$ & 4.7 & 11.0 & 16.3 & 3.1 & 32 & 14 & 1 & 24 & 74.1 & 66 \\
\hline & $0.1-0.2$ & 4.9 & 11.0 & 12.4 & 2.6 & 27 & 13 & 1 & 17 & 60.6 & 70 \\
\hline & $0.2-0.3$ & 4.5 & 11.0 & 5.6 & 0.8 & 29 & 12 & 1 & 17 & 59.8 & 70 \\
\hline & $0.3-0.4$ & 4.6 & 8.0 & 3.2 & 0.4 & 14 & 8 & 2 & 14 & 38.4 & 58 \\
\hline & $0.4-0.6$ & 4.3 & 8.0 & 3.5 & 0.5 & 12 & 5 & 3 & 19 & 39.5 & 44 \\
\hline & $0.6-0.8$ & 4.4 & 9.0 & 4.3 & 0.5 & 13 & 7 & 3 & 17 & 40.5 & 51 \\
\hline & $0.8-1.0$ & 4.8 & 8.0 & 3.4 & 0.5 & 12 & 6 & 2 & 14 & 34.5 & 54 \\
\hline \multirow{7}{*}{$\begin{array}{l}\bar{\sigma} \\
\frac{0}{0} \\
\text { ó } \\
\text { ì }\end{array}$} & $0.0-0.1$ & 4.9 & 14.0 & 13.5 & 2.6 & 36 & 17 & 1 & 15 & 71.6 & 78 \\
\hline & $0.1-0.2$ & 5.0 & 11.0 & 20.1 & 1.8 & 39 & 18 & 1 & 12 & 71.8 & 82 \\
\hline & $0.2-0.3$ & 5.0 & 9.0 & 12.7 & 0.9 & 26 & 14 & 1 & 12 & 53.9 & 76 \\
\hline & $0.3-0.4$ & 4.7 & 8.0 & 11.7 & 0.9 & 25 & 12 & 1 & 15 & 53.9 & 70 \\
\hline & $0.4-0.6$ & 4.3 & 6.0 & 10.8 & 0.5 & 12 & 7 & 2 & 13 & 34.5 & 57 \\
\hline & $0.6-0.8$ & 4.5 & 6.0 & 10.4 & 0.7 & 25 & 12 & 1 & 12 & 50.7 & 74 \\
\hline & $0.8-1.0$ & 4.2 & 7.0 & 8.3 & 0.4 & 12 & 7 & 1 & 15 & 35.4 & 55 \\
\hline \multirow{7}{*}{ 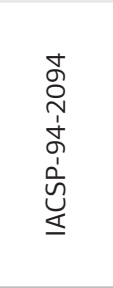 } & $0.0-0.1$ & 5.0 & 16.0 & 20.1 & 4.3 & 31 & 12 & 1 & 14 & 62.3 & 76 \\
\hline & $0.1-0.2$ & 5.2 & 15.0 & 17.3 & 3.8 & 24 & 12 & 1 & 11 & 51.8 & 77 \\
\hline & $0.2-0.3$ & 5.1 & 13.0 & 10.8 & 1.6 & 23 & 13 & 1 & 14 & 52.6 & 72 \\
\hline & $0.3-0.4$ & 5.0 & 7.0 & 8.6 & 0.7 & 20 & 10 & 1 & 17 & 48.7 & 63 \\
\hline & $0.4-0.6$ & 4.6 & 8.0 & 9.9 & 0.3 & 8 & 4 & 3 & 19 & 34.3 & 36 \\
\hline & $0.6-0.8$ & 4.5 & 8.0 & 7.3 & 0.3 & 9 & 5 & 3 & 12 & 29.3 & 49 \\
\hline & $0.8-1.0$ & 4.7 & 7.0 & 4.8 & 0.3 & 9 & 5 & 3 & 15 & 32.3 & 44 \\
\hline
\end{tabular}


$\mathrm{L}_{\mathrm{A}}$ decreased as depth increased, following an exponential shape (Smith et al., 2005). In fact, the adopted cultivars showed an accurate adjust to exponential fitting (Table 3). According to the equation parameters, it could be observed
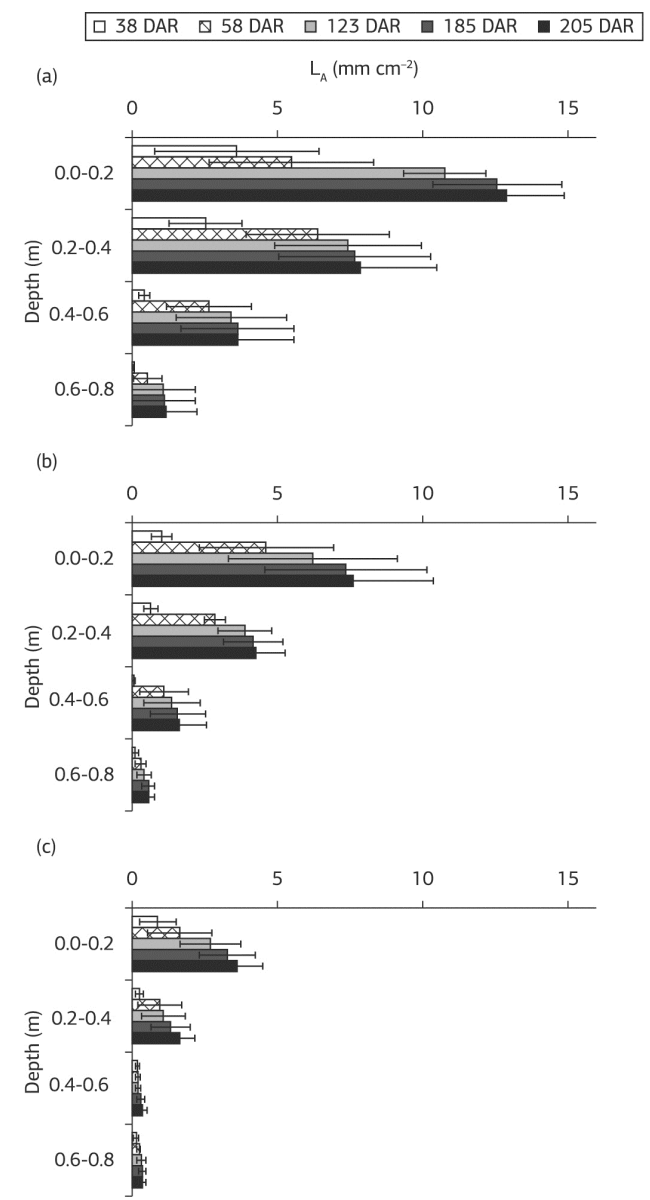

Figure 4. Cumulative root density $\left(\mathrm{L}_{\mathrm{A}}\right)$ in sugarcane cultivars IACSP94-2101 (a), SP79-1011 (b) and IACSP94-2094 (c) in five assessments up to $0.8 \mathrm{~m}$ depth. Each bar represents the mean value of three replications ( \pm s.e.). DAR $=$ days after ratoon.

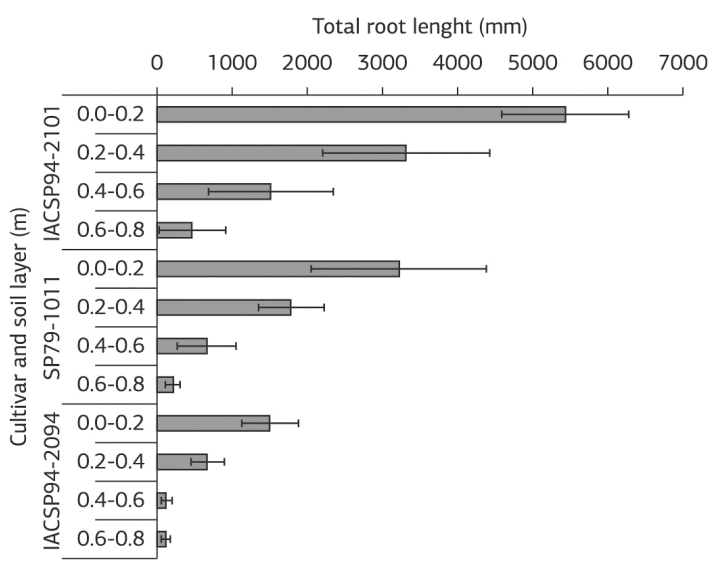

Figure 5. Total root length $(\mathrm{mm})$ distribution in sugarcane cultivars SP79-1011, IACSP94-2094 and IACSP94-2101 at 205 days after ratoon (DAR) in different soil layers, up to $0.8 \mathrm{~m}$. Each bar represents the mean value of three replications ( \pm s.e.). that the main difference between the equations is the "a" coefficient, which value is higher for IACSP94-2101 and lower to IACSP94-2094. The $\mathrm{L}_{\mathrm{A}}$ value will be higher as the "a" coefficient increases, since they are directly proportional. The $\mathrm{Z}$ parameter, which represents the depth in the soil profile, is in the equation exponent, which it indicates that $\mathrm{L}_{\mathrm{A}}$ will decrease exponentially with depth. As well as $\mathrm{Z}$, the " $\mathrm{b}$ " coefficient in the exponent means that $\mathrm{L}_{\mathrm{A}}$ is expected to decrease exponentially with the decrease of the "b" coefficient. Thus, comparing the "a" and "b" coefficients, it was observed higher "a" and " $b$ " values for IACSP94-2101, indicating that this cultivar had higher $\mathrm{L}_{\mathrm{A}}$ values and the exponential decrease of $\mathrm{L}_{\mathrm{A}}$ values, considering the same $\mathrm{Z}$ value, was less pronounced than the other cultivars.

Considering the use of minirhizotron method to evaluate sugarcane root system under field conditions, Ball-Coelho et al. (1992) estimated a mean value of $2.7 \mathrm{~m} \mathrm{~m}^{-2}$ up to $1.5 \mathrm{~m}$ depth. These values are lower than it was observed in our study, but it is important to highlight that Ball-Coelho et al. (1992) considered the mean value up to $1.5 \mathrm{~m}$ depth and the tube used had a different shape.

Although Azevedo et al. (2011), Laclau \& Laclau (2009), Otto et al. (2009) and Vasconcelos et al. (2003) have studied sugarcane root system, they used other methods, which difficult the comparison based on the value itself. However, all of them reported large variability for root evaluations such as root mass and length. High variability in $\mathrm{L}_{\mathrm{A}}$ was also observed herein, based on the standard error of the mean (Figure 4), especially in the early growth stage and in deeper layers.

As root growth is dependent on cultivar, soil biologicalphysical-chemical status, crop management (Vasconcelos et al., 2003) and also soil water availability (Laclau \& Laclau, 2009; Smith et al., 2005), studies about root dynamics must be done in different growing conditions and using the same method to improve our understanding about sugarcane root system.

\section{Root distribution and effective rooting depth}

As a perennial crop, sugarcane root distribution increases in the upper soil layers at later growth stages (Gascho \& Shih, 1983) and this pattern of response was verified herein

Table 3. Equation adjust coefficients ( $\mathrm{a}$ and $\mathrm{b}$ ) to exponential equation for $\mathrm{L}_{\mathrm{A}}$ estimation and its correlation coefficients $(\mathrm{r})$ in sugarcane cultivars SP79-1011, IACSP94-2094 and IACSP94-2101 at 205 days after ratoon (DAR) up to $0.8 \mathrm{~m}$ depth. The $\mathrm{Z}$ parameter represents the depth in the soil profile

\begin{tabular}{lccc|}
\multicolumn{1}{c}{ Cultivar } & a & b & r \\
\hline IACSP94-2101 & 18.03 & -3.15 & 0.99 \\
\hline SP79-1011 & 11.16 & -3.61 & 0.99 \\
IACSP94-2094 & 5.72 & -4.58 & 0.99 \\
\hline Equation $\left(\mathrm{y}=\mathrm{ae}^{\mathrm{bx})}\right.$ & $\mathrm{L}_{\mathrm{A}}=\mathrm{ae}^{\mathrm{bz}}$ & & \\
\hline
\end{tabular}


(Figure 4, Table 4). The minirhizotron method allowed the observation of changes in root distribution and even in the effective rooting depth (Table 4). Understanding the root distribution along the crop cycle could provide useful information for water management based on the phenological crop stage. As irrigation depth is adjusted in according to the ERD, this parameter is especially important to water management. The knowledge about ERD variation along the crop cycle could be especially useful for supplementary irrigations. Cultivars with higher ERD exploit larger soil volume and hence they could have higher soil available water. Higher ERD also enables better use of rainfall.

Most of roots in all three cultivars were found at the first $0.2 \mathrm{~m}$ soil layer, reaching more than $50 \%$ at $205 \mathrm{DAR}$. If the depth of $0.4 \mathrm{~m}$ is considered, more than $80 \%$ of the root system was found (Table 4). Therefore, the effective rooting depth (ERD) was $0.4 \mathrm{~m}$ in all cultivars at $205 \mathrm{DAR}$, which is in accordance to Landell et al. (2005). An interesting finding is that IACSP94-2094 has varied its ERD during the cycle, from $0.6 \mathrm{~m}$ at $58 \mathrm{DAR}$ to $0.4 \mathrm{~m}$ at $123 \mathrm{DAR}$ (Table 4). Soil water content was also higher at the upper soil layers (Figure 3), which also affect the pattern of root distribution (Laclau \& Laclau, 2009; Smith et al., 2005).

The conversion of $\mathrm{L}_{\mathrm{A}}$ values to percentage values not only allows the ERD determination but also the comparison with other studies. Otto et al. (2009) have also found 65\% of root mass in the first $0.2 \mathrm{~m}$ soil layer when evaluating the cultivar SP81-3250. Similar results were reported by Vasconcelos et al. (2003), with $52 \%$ of root mass in the superficial soil layer. Both studies were carried out without irrigation, but only Otto et al. (2009) have reported more than $80 \%$ of root mass up to $0.4 \mathrm{~m}$ depth. Despite of not showing the relative values, Azevedo et al. (2011) and Laclau \& Laclau (2009) also found higher root density up to $0.4 \mathrm{~m}$ depth. Typical values for sugarcane root mass up to 0.2 and $0.6 \mathrm{~m}$ depth are $50 \%$ and $85 \%$, respectively (Smith et al., 2005).
Our results indicate that root distribution tend to be higher than $50 \%$ up to $0.2 \mathrm{~m}$ depth and more than $80 \%$ of total root system up to $0.4 \mathrm{~m}$ depth under subsurface drip fertigation. The knowledge of root growth and distribution are important parameters to improve the water and nutrient management and hence the use efficiency of these inputs, especially when using subsurface drip fertigation system. In addition, root growth and distribution are relevant parameters for models to forecasting production.

\section{Root growth}

The highest root growth rates occurred between 38 and 58 DAR, with IACSP94-2101 also showing high growth rates between 0 and 38 DAR (Figure 6a). It was observed root growth variation in soil profile, with growth rate decreasing with increasing in soil depth (Figure 6). The maximum root growth rate was $82 \mathrm{~mm} \mathrm{day}^{-1}$ in IACSP94-2101 at the 0.2-0.4 m soil layer, which was similar to that one reported by Smith et al. (2005), i.e., $80 \mathrm{~mm} \mathrm{day}^{-1}$. The highest growth rates occurred when air temperature varied between 25.0 and $27.9^{\circ} \mathrm{C}$ and there was water availability (Figure 1). This period coincided with the intense tillering phenological stage, when vigorous root growth is required to support subsequent tiller growth (Vasconcelos \& Casagrande, 2008). Laclau \& Laclau (2009) reported low initial root growth rates (up to $5.3 \mathrm{~mm} \mathrm{day}^{-1}$ ), which increased to $17.5 \mathrm{~mm}$ day $^{-1}$ in irrigated plants. Smit \& Groenwold (2005) have shown different rates of downward root movement among several crops, with grasses showing the lowest ones about $20 \mathrm{~mm}$ day ${ }^{-1}$.

While IACSP94-2094 had root growth rate of $7.4 \mathrm{~mm}$ day $^{-1}$ at the upper soil layer, IACSP94-2101 presented growth rates higher than $25 \mathrm{~mm} \mathrm{day}^{-1}$ (Figure 6b). Then, our data revealed a large genotypic variation in root growth in commercial sugarcane cultivars (Figure 6b). As growth rates of IACSP94-2101 were similar to those ones reported

Table 4. Cumulative $\mathrm{L}_{\mathrm{A}}$ distribution (\%) up to $0.8 \mathrm{~m}$ depth sampled during crop cycle of three sugarcane cultivars. DAR means days after ratoon. $\mathrm{L}_{\mathrm{A}}=$ cumulative root density $\left(\mathrm{mm} \mathrm{cm}^{-2}\right)$

\begin{tabular}{|c|c|c|c|c|c|c|}
\hline \multirow{2}{*}{ Cultivar } & \multirow{2}{*}{ Depth (m) } & \multicolumn{5}{|c|}{ Cumulative root distribution (\%) } \\
\hline & & 38 DAR & 58 DAR & 123 DAR & 185 DAR & 205 DAR \\
\hline \multirow{4}{*}{ IACSP94-2101 } & $0.0-0.2$ & 48.0 & 35.2 & 50.9 & 53.5 & 53.6 \\
\hline & $0.2-0.4$ & 91.9 & 82.0 & 92.2 & 82.8 & 83.1 \\
\hline & $0.4-0.6$ & 98.9 & 96.8 & 95.8 & 96.0 & 96.0 \\
\hline & $0.6-0.8$ & 100.0 & 100.0 & 100.0 & 100.0 & 100.0 \\
\hline \multirow{4}{*}{ SP79-1011 } & $0.0-0.2$ & 57.5 & 49.8 & 50.0 & 53.0 & 53.3 \\
\hline & $0.2-0.4$ & 93.4 & 86.2 & 85.1 & 84.7 & 84.5 \\
\hline & $0.4-0.6$ & 96.0 & 96.3 & 95.5 & 95.3 & 95.3 \\
\hline & $0.6-0.8$ & 100.0 & 100.0 & 100.0 & 100.0 & 100.0 \\
\hline \multirow{3}{*}{ IACSP94-2094 } & $0.0-0.2$ & 54.5 & 53.0 & 61.6 & 62.3 & 60.4 \\
\hline & $0.2-0.4$ & 70.9 & 77.4 & 83.9 & 85.5 & 87.1 \\
\hline & $0.4-0.6$ & 87.9 & 88.4 & 89.7 & 92.2 & 93.6 \\
\hline
\end{tabular}




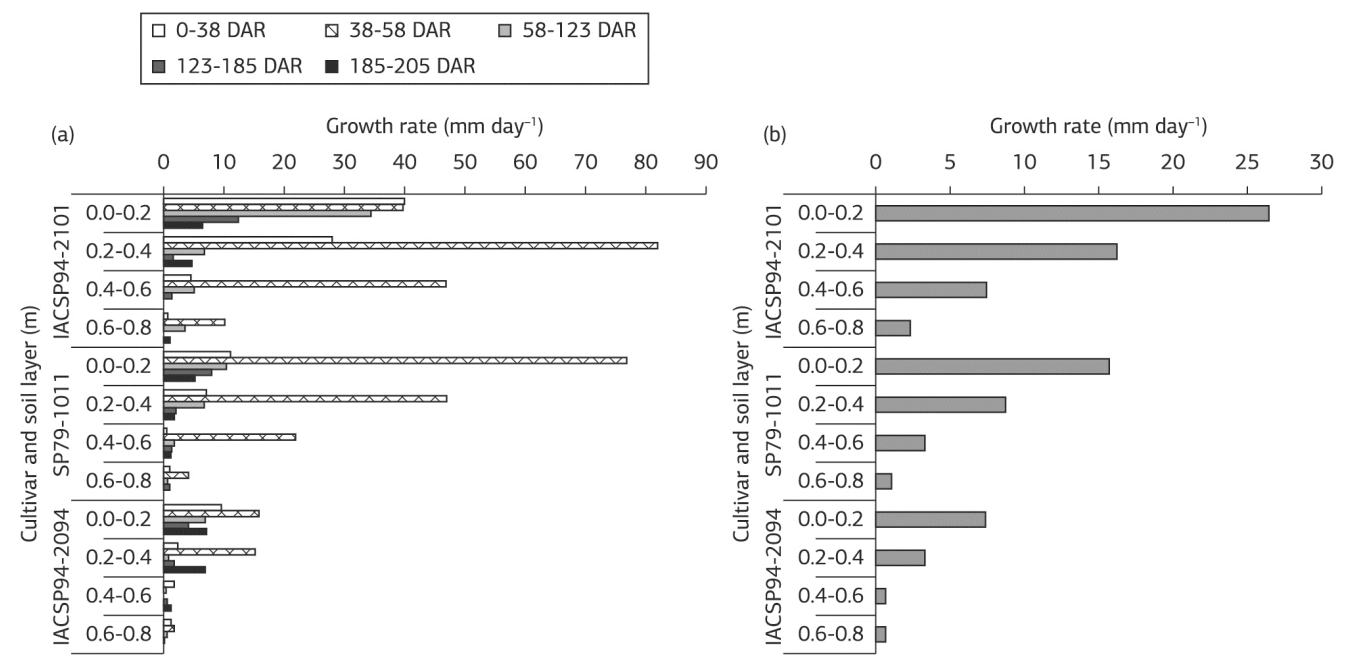

Figure 6. Root growth rate in each soil layer up to $0.8 \mathrm{~m}$ depth for sugarcane cultivars IACSP94-2101, SP79-1011 and IACSP94-2094 in five assessments periods (a) and overall root growth rate in 205 days (b). DAR = days after ratoon.

by Smit \& Groenwold (2005), we may argue that SP79-1011 and IACSP94-2094 presented smaller root growth in ratoon crop. This trait may be associated with its unresponsiveness to favorable environmental conditions (Landell \& Bressiani, 2008), suggesting a conservative strategy of resource use. The higher growth rates presented by IACSP94-2101 could be related to its fast initial vegetative growth and high yield (Landell \& Bressiani, 2008).

Understanding the root growth rates along the crop cycle provides information about the phenological stage in which the higher root growth rate was observed. Thus, this information could be useful for irrigation and nutrition management purposes aiming to avoid potential restrictions related to the high growth demand.

\section{CONCLUSION}

The highest cumulative root densities $\left(\mathrm{L}_{\mathrm{A}}\right)$ and root growth rates were found up to $0.4 \mathrm{~m}$ soil layer for all cultivars. Root growth varied during crop cycle, with the highest values being found between 38 and 58 days after ratoon. There was a genotypic variation in root growth, with IACSP94-2101 showing the highest $\mathrm{L}_{\mathrm{A}}$ of $12.9 \mathrm{~mm} \mathrm{~cm} \mathrm{~m}^{-2}$. The effective rooting depth varied during crop cycle for IACSP94-2094, but all cultivars presented an effective depth of $0.4 \mathrm{~m}$ under subsurface drip fertigation.

\section{ACKNOWLEDGEMENTS}

This study was supported by grants from São Paulo Research Foundation (FAPESP), grant \#2011/16174-2, and FAPESP/Microsoft Research Connections - BIOEN, grant \#2010/52139-4. RCMP and RVR acknowledge the fellowships granted by the National Council for Scientific and Technological Development (CNPq, Brazil).

\section{REFERENCES}

Allen, R. G., Pereira, L. S., Raes, D., \& Smith, M. (1998). Crop evapotranspiration : guidelines for computing crop water requirements (FAO Irrigation and Drainage Paper, No. 56). Roma: FAO.

Azevedo, M. C. B., Chopart, J. L., \& Medina, C. C. (2011). Sugarcane root length density and distribution from root intersection counting on a trench-profile. Scientia Agricola, 68, 94-101. http://dx.doi. org/10.1590/S0103-90162011000100014.

Ball-Coelho, B., Sampaio, E. V. S. B., Tiessen, H., \& Stewart, J. W. B. (1992). Root dynamic in plant-ratoon crop of sugar cane. Plant and Soil, 142, 297-305. http://dx.doi.org/10.1007/BF00010975.

Baquero, J. E., Ralisch, R., Medina, C. C., Tavares, J., Fo., \& Guimarães, M. F. (2012). Soil physical properties and sugarcane root growth in a red oxisol. Revista Brasileira de Ciencia do Solo, 36, 63-70. http:// dx.doi.org/10.1590/S0100-06832012000100007.

Blain, G. C. (2009). Considerações estatísticas relativas à oito séries de precipitação pluvial da Secretaria de Agricultura e abastecimento do Estado de São Paulo. Revista Brasileira de Meteorologia, 24, 12-23. http://dx.doi.org/10.1590/S0102-77862009000100002.

Box, J., E. Jr. (1993). Use of the minirhizotron-miniature video camera technique for measuring root dynamics. Geoderma, 56, 133-141. http://dx.doi.org/10.1016/0016-7061(93)90105-T.

Cunha, F. F., Ramos, M. M., Alencar, C. A. B., Martins, C. E., Cóser, A. C., \& Oliveira, R. A. (2010). Sistema radicular de seis gramíneas irrigadas em diferentes adubaçôes nitrogenadas e manejos. Acta Scientiarum Agronomy, 32, 351-357. http://dx.doi.org/10.4025/ actasciagron.v32i2.1020. 
Dannoura, M., Kominami, Y., Oguma, H., \& Kanazawa, Y. (2008). The development of an optical scanner method for observation of plant root dynamics. Plant Root, 2, 14-18. http://dx.doi.org/10.3117/ plantroot.2.14.

Empresa Brasileira de Pesquisa Agropecuária - EMBRAPA (2013). Sistema Brasileiro de Classificaçáo de Solos (3rd ed.). Brasilia: Embrapa.

Gascho, G. J., \& Shih, S. F. (1983). Sugarcane. In I. D. Teare, \& M. M. Peet (Eds.), Crop-water relations (p. 445-479). United States of America: John Wiley \& Sons Inc.

Hyams, D. (2009). CurveExpert version 1.4.

Kandelous, M. M., \& Šimůnek, J. (2010). Comparison of numerical, analytical, and empirical models to estimate wetting patterns for surface and subsurface drip irrigation. Irrigation Science, 28, 435-444. http:// dx.doi.org/10.1007/s00271-009-0205-9.

Kirkham, M. B., Grecu, S. J., \& Kanemasu, E. T. (1998). Comparison of minirhizotrons and the soil-water-depletion method to determine maize and soybean root length and depth. European Journal of Agronomy, 8, 117-125. http://dx.doi.org/10.1016/S1161-0301(97)00019-1.

Laclau, P. B, \& Laclau, J. P. (2009). Growth of the whole root system for a plant crop of sugarcane under rainfed and irrigated environments in Brazil. Field Crops Research, 114, 351-360. http:// dx.doi.org/10.1016/j.fcr.2009.09.004.

Landell, M. G. A., \& Bressiani, J. A. (2008). Melhoramento genético, caracterizaçáo e manejo varietal. In L. L. Dinardo-Miranda, A. C. M. Vasconcelos, \& M. G. A. Landell (Eds.), Cana-de-açúcar (p. 101-155). Campinas: Instituto Agronômico.

Landell, M. G. A., Campana, M. P., Figueiredo, P., Vasconcelos, A. C. M., Xavier, M. A., Bidoia, M. A. P., Prado, H., Silva, M. A., Dinardo-Miranda, L. L., Santos, A. S., Perecin, D., Rossetto, R., Silva, D. N., Martins, A. L. M., Gallo, P. B., Kantak, R. A. D., Cavichioli, J. C., Veiga, A. A., Fo., Anjos, I. A., Azania, C. A. M., Pinto, L. R., \& Souza, S. A. C. D. (2005). Variedades de cana-de-açúcar para o Centro-Sul do Brasil (Boletim Técnico, No. 197). Campinas: Instituto Agronômico.

Liu, D. L., Kingston, G., \& Bull, T. A. (1998). A new technique for determining the thermal parameters of phenological development in sugarcane, including suboptimum and supra-optimum temperature regimes. Agricultural and Forest Meteorology, 90, 119-139. http:// dx.doi.org/10.1016/S0168-1923(97)00087-7.

Muñoz-Romero, V., Benítez-Vega, J., López-Bellido, L., \& LópezBellido, R. J. (2010). Monitoring wheat root development in a rainfed vertisol: tillage effect. European Journal of Agronomy, 33, 182-187. http://dx.doi.org/10.1016/j.eja.2010.05.004

Otto, R., Trivelin, P. C. O., Franco, H. C. J., Faroni, C. E., \& Vitti, A. C. (2009). Root system distribution of sugar cane as related to nitrogen fertilization, evaluated by two methods: monolith and probes. Revista Brasileira de Ciencia do Solo, 33, 601-611. http:// dx.doi.org/10.1590/S0100-06832009000300013.

Quaggio, J. A., \& van Raij, B. (2008). Cálcio, magnésio e correção da acidez do solo. In L. L. Dinardo-Miranda, A. C. M. Vasconcelos, \& M. G. A. Landell (Eds.), Cana-de-açúcar (p. 313-321). Campinas: Instituto Agronômico.

Reichert, J. M., Suzuki, L. E. A. S., Reinert, D. J., Horn, R., \& Håkansson, I. (2009). Reference bulk density and critical degreeof-compactness for no-till crop production in subtropical highly weathered soils. Soil \& Tillage Research, 102, 242-254. http://dx.doi. org/10.1016/j.still.2008.07.002.

Smit, A. L., George, E., \& Groenwold, J. (2000). Root observations and measurements at (transparent) interfaces with soil. In A. L. Smit, A. G. Bengough, C. Engels, M. Van Noordwijk, S. Pellerin, \& S. C. Van De Geijn (Eds.), Root methods: a handbook (p. 235-271). Germany: Springer-Verlag Berlin Heidelberg.

Smit, A. L., \& Groenwold, J. (2005). Root characteristics of selected field crops: data from the Wageningen Rhizolab (1990-2002). Plant and Soil, 272, 365-384. http://dx.doi.org/10.1007/s11104-004-5979-1.

Smith, D. M., Inman-Bamber, N. G., \& Thorburn, P. J. (2005). Growth and function of the sugarcane root system. Field Crops Research, 92, 169-183. http://dx.doi.org/10.1016/j.fcr.2005.01.017.

Sojka, R. E., Busscher, W. J., Gooden, D. T., \& Morrison, W. H. (1990). Subsoiling for sunflower production in the Southeast Coastal Plains. Soil Science Society of America Journal, 54, 1107-1112. http:// dx.doi.org/10.2136/sssaj1990.03615995005400040031x

Stolf, R., Fernandes, J., \& Furlani, V. L., Fo. (1983). Penetrômetro de impacto modelo IAA/Planalsucar-Stolf: recomendação para seu uso. In J. M. Anderson, \& J. S. I. Ingram (Eds.), Tropical soil biology and fertility: a hand book of methods (p. 132-144). Wallingford: CAB International.

van Noordwijk, M. (1993). Roots: length, biomass, production and mortality (p. 132-144). In J. M. Anderson \& J. S. I. Ingram (Eds.), Tropical soil biology and fertility: a hand book of methods. Wallingford: CAB International.

van Raij, B., Cantarella, H., Quaggio, J. A., \& Furlani, A. M. C. (1996). Recomendções de adubaçáo e calagem para o Estado de São Paulo (2nd ed., Boletim Técnico, No. 100). Campinas: IAC.

Vasconcelos, A. C. M., Casagrande, A. A., Perecin, D., Jorge, L. A. C., \& Landell, M. G. A. (2003). Avaliação do sistema radicular da canade-açúcar por diferentes métodos. Revista Brasileira de Ciencia do Solo, 27, 849-858. http://dx.doi.org/10.1590/S0100-06832003000500009.

Vasconcelos, A. C. M., \& Casagrande, A. A. (2008). Fisiologia do sistema radicular. In L. L. Dinardo-Miranda, A. C. M. Vasconcelos, \& M. G. A. Landell (Eds.), Cana-de-açúcar (p. 79-97). Campinas: Instituto Agronômico. 